\title{
Early Greek Cosmology: A Historiographical Review
}

\section{Norriss S. Hetherington*}

\section{Introduction}

Early Greek cosmology has attracted much attention from classicists, historians, philosophers, and scientists, with each group bringing to the subject its own interests and biases. Purportedly authoritative reconstructions and analyses of ancient Greek cosmology exist in abundance, even though no philosophical writings of the Presocratic period, circa 600 to $400 \mathrm{BC}$, have survived. The Greeks' attempt to explain celestial phenomena in natural terms and to avoid supernatural or divine intervention is a common theme linking many otherwise disparate scholarly studies. A frequent point of dispute involves the degree to which ancient ideas are to be judged in the context of modern science.

From scientist-historians, by which I mean scientists who have become historians, we have, in the words of Victor Thoren, 'modern commentaries, written fairly uniformly over the last 150 years by men uniformly possessed of more astronomical ingenuity than historical perspective or critical sense. The result is a corpus of secondary material replete with literally incredible claims, many of them mutually (and some of them self-) contradictory. ${ }^{1}$ At the other end of the scholarly spectrum reside classicists, producing philological rather than philosophical or historical books. As William Stahlman wrote, 'The trees are here and accurately labelled, but we never see the forest. ${ }^{2}$

Between these two extremes lie a few studies of ancient Greek cosmology in its cultural context, most often focusing on the Ionian school, or Milesians, chiefly Thales (c.600 BC), Anaximander (c.610-545 BC), Anaximenes (c.546 BC) and Heraclitus (c.540-c.480 BC), and Pythagoras (b.c.570/580 BC) and the Pythagoreans. ${ }^{3}$ It is these who chiefly concern me here. However, neither most of the accounts of the Milesians nor the Pythagoreans adequately cover all the varieties of Presocratic cosmological thought, and historians are open to the charge of over-simplification, that "for long enough we have thought of early Greek philosophy as a tennis match between Ionians and Italians, with all the Greeks in the middle gaping dumbly up as the ball flew to and fro above their heads'. ${ }^{4}$

\section{Sources}

* University of California, Berkeley, 
One of the most useful and convenient collections of the raw materials for reconstructions and analyses is contained in The Presocratic Philosophers by Kirk, Raven, and Schofield. Their work includes extant fragments, mainly a few quotations from Presocratic works that have survived in books written after $400 \mathrm{BC}$, with the Greek original and English translation, and commentaries. Their principal sources are testimonia, comments in the writings, such as have survived, of Plato, Aristotle, and Theophrastus, written shortly after the Presocratic period; and the doxographical tradition, consisting of summaries of the works of Plato, Aristotle, and Theophrastus, and summaries of summaries, the primary source for the summarizers being the multi-volume history of early philosophy by Theophrastus. ${ }^{5}$

Yet none of the surviving sources is above question. The fragments probably are the most reliable, or least unreliable, but there is no surviving original against which to check them. The testimonia have an additional uncertainty. Aristotle gives serious attention to the earlier philosophers, but his judgment and his corresponding analysis and description of earlier philosophy may well have been distorted by his own belief in the importance of the material nature of the world. He desired 'to find predictions of his own conclusions in the works of his predecessors'. 6 Plato, in contrast, offers only casual remarks on his predecessors. Just how little has survived is illustrated by the example of Theophrastus. Of the approximately eighteen books he wrote, at most a handful have survived, and the doxographical tradition consists primarily of summaries of his books and summaries of summaries.

Classicists are virtually unanimous in doubting the reliability of the surviving sources, though with differing degrees of forcefulness. In Early Greek Astronomy to Aristotle, D. R. Dicks' argumentative scepticism left readers with a decidedly negative aftertaste. ${ }^{7} \mathrm{He}$ was even more polemical and irritating in journal articles and in 1966 he wrote that 'The literature is now full of references to the scientific achievements (socalled) of the Presocratics, and the earlier the figure (and consequently the less information of reliable authenticity we have of him) the more enthusiastically do scholars enlarge his scientific knowledge'... ${ }^{8}$ Thales is the earliest such figure and Dicks considered that 'Inevitably there accumulated round the name of Thales, as that of Pythagoras (the two often being confused), a number of anecdotes of varying degrees of plausibility and of no historical worth whatsoever'.

\section{Speculation or Science?}


Having dispensed with modern scholars, Dicks turned on their ancient subject, the Presocratics. He argued that 'Greek astronomy was still in the pre-scientific stage. Observations of astronomical phenomena...were rough-and-ready observations, unsystematically recorded and imperfectly understood, of practical men... whose main concern was to have some sort of guide for the regular business of everyday life...Ionian speculation seems to have taken very little note of such observation (some of its wilder flights of fancy might have been avoided, if it had taken more)...Not until Ionian speculation had played itself out and it was becoming increasingly obvious that such presumptive theorising bore little or no relation to the gradually accumulating stock of observational data, did mathematical astronomy even begin to develop'. ${ }^{10}$

In response to Dicks' characterisation of Ionian philosophy as a speculative enterprise without a scientific future and a philosophic sideline with no impact on the development of observational science or mathematical astronomy, one critic charged that what he offered was 'essentially a Baconian or neo-Baconian view of science which admits mathematical computation together with empirical observation as the necessary characteristics of science, but which denies any role to speculative hypotheses of a strongly theoretical nature'. ${ }^{11}$ A classicist limiting himself to Greek and Roman subjects, Dicks did not look ahead to the influence of Pythagorean number mysticism on modern science and he gave short shrift to the cosmological fantasies of the Presocratics, rejecting sweeping statements from other scholars about supposed striking similarities between patterns of thought in ancient Greek and modern science. He did, though, concede that the Pythagoreans were beginning to move away from speculative thinking. Other scholars have seen in emerging Ionian rationalism the removal almost at a single stroke of the entire mythological scaffolding of earlier, pre-scientific thought. ${ }^{12}$

\section{Ionian Rationalism}

Focusing on the method rather than substance of Presocratic thought avoids the difficulty that most Presocratic theories are known to be false. To put it bluntly, as Jonathan Barnes did, 'none of the Milesian theories is true: the Milesians do not compose a Greek Royal Society; and their Transactions would not make any contribution to the sum of scientific knowledge'. Further, by focusing on the rational, philosophical element within Presocratic methodology rather than the mathematical, quantifiable element, historians can avoid the difficulty that 'none of the Milesians aspired to the sort of precision we require in a scientific theory: 
their views are incurably vague; and underlying this vagueness is a complete innocence of the delights of measurement and quantification'. ${ }^{13}$

An emphasis on rationalism as a key characteristic of Presocratic cosmology also fits nicely with the 'Greek miracle' view of ancient history. Simply stated this holds that in the beginning there were 'charming but childish Egyptians and Sumerians with their weird and fantastic notions about the cow-goddess in the sky, the sweet waters under the earth, and so on, and then along came the Greeks who were adult rational people like ourselves'. 14

Francis Cornford, a historian of ancient philosophy, did much to establish the belief in the miracle of Presocratic rationalism. In From Religion to Philosophy, first published in 1912 but still popular, he commented on the absence from Milesian philosophy of astrological superstition, magical powers, and mythical cosmogony. Less noted by readers is his conclusion that the advent of the new rational spirit was not a sudden and complete breach with the old, and that there remained a thread of continuity from science back to the supernatural world of the gods. $^{15}$

Cornford's thesis has not been superseded, even if part of it, no doubt compatible with prevailing theories of race in England early in the twentieth century, now risks being found less than perfectly politically correct. 'The scientific tendency is Ionian in origin: it takes its rise among that race which had shaped Homeric theology, and it is the characteristic product of the same racial temperament.' ${ }^{16}$ Cornford's Presocratics also aspired to be modern scientists. 'The aim of science...triumphantly achieved...succeeded in reducing physics to a perfectly clear, conceptual model, such as science desires... ${ }^{17}$ But the Presocratics could not have known what lay in the future. 'They were not trying to give a scientific system, since no one yet had told them what "science" ought to be. 18

By the 1930s Cornford had forged general agreement on the proposition that with Thales what we call western science first appeared in the world. He wrote that 'The intelligence became disinterested and now felt free to voyage on seas of thought strange to minds bent on immediate problems of action. Reason sought and found truth that was universal, but might, or might not, be useful for the exigencies of life...Science begins when it is understood that the universe is a natural whole, with unchanging ways of its own - ways that may be ascertainable by human reason, but are beyond the control of human action'. ${ }^{19}$ With the rise of science, he thought, there occurred a corresponding demise of 
magic and mythology, themselves pre-scientific practices designed to bring supernatural forces under some measure of control.

Later, Cornford had second thoughts. All his life he was a dissenter, and ultimately he dissented against the proposition he had done so much to establish, that Ionian natural philosophers were scientific. Now he noted that their dogmatic pronouncements easily could have been upset by careful observation or the simplest experiment, but they had no empirical theory of knowledge to govern their speculations. ${ }^{20}$ Published only posthumously, Cornford's second thoughts still have not entirely overtaken his first. A new generation of historians is more sensitive to the unscientific nature of Presocratic science, but some writers still single out rationalism, seemingly unaware both that they are echoing Cornford and that he has retracted much of the foundation upon which their derivative accounts are constructed. It is not inconsistent, however, to maintain that the Presocratics had a scientific world-view even though they lacked the experimental method. ${ }^{21}$

Benjamin Farrington was prominent amongst those who emphasised the rational in Presocractic cosmology. In his Science in Antiquity, he traced the development of ancient science in close relation to the history of philosophy. For the Milesians, he argued that Thales' importance lay in his being the first person known to have offered a general explanation of nature without invoking the aid of any outside power. He concluded that Anaximander's brilliant advance was toward a more abstract conception of nature; no longer was the underlying substance of the material world a visible, tangible state of matter, such as water, but the lowest common denominator of all sensible things arrived at by a process of abstraction.

Farrington placed the Pythagoreans, on the other hand, in a context of a spiritual revival brought about by the menace of the Persian advance, arguing that Pythagorean mathematics was primarily a religious exercise. $^{22}$ Here he was followed by other scholars, such as June Goodfield and Stephen Toulmin, who argued that 'Pythagoras, it is clear, was not so much the leader of a scientific research team, or the principal of an educational establishment, as (in modern terms) the guru of an Indian ashram'. ${ }^{23}$ Earlier Bertrand Russell had found modern parallels for Pythagoras when he described him as 'a combination of Einstein and Mrs. Eddy'. ${ }^{24}$

\section{Science and Society}


Farrington forged a very different thesis in Greek Science, exploring connections with practical life, with techniques, and with the economic basis and productivity of Greek society. A Marxist, he was interested in the effect of class interests in determining early Greek philosophical opinion. Egyptian and Babylonian cosmogonies, known to Thales, had embodied the idea of water in the beginning, probably because the land in both countries had been won in a desperate struggle with nature by draining swamps. Thales, leaving out only the god who had let dry land be, still formed everything out of water. Farrington seemingly chose to ignore Aristotle's speculation that Thales may have arrived at his supposition from seeing the nurture of all things to be moist. Continuing his emphasis on the practical, Farrington speculated that Heraclitus chose fire as the first principle perhaps because it was the active agent which produced change in so many technical and natural processes. In marked contrast was Pythagorean society, in which contempt for manual labour kept pace with the growth of slavery and technical processes of production became more shameful, fit only for slaves. How fortunate and acceptable that the secret constitution of things was revealed not to those who manipulated nature but to the thinkers. This, Farrington speculated, marked the separation of philosophy from the techniques of production. ${ }^{25}$

The possible links between Presocratic cosmology and its social setting are not limited to Farrington's imagination. Jean Pierre Vernant set out to explain the change from arithmetical Babylonian astronomy to geometrical Greek cosmology by arguing from the general premise that social change preceded philosophical. Thus the rationalisation of science and cosmology followed the secularisation and rationalisation of political administration. He related this process to the reorganisation of social space within the city and the appearance of the open central public space, the agora, in Ionian and Greek cities. Consequently, he argued that cosmological space was reorganised when Anaximander placed the earth in the centre of the universe. ${ }^{26}$ Such speculation seems to have quickly exhausted the few facts we think we know regarding the Presocratics.

While Farrington, the Marxist, argued that science and cosmology are derived from social structures and needs, others have searched for ways in which science and cosmology influenced society. The historian of science, Richard Olson, for instance, has sought out instances of the extension and application of scientific attitudes and modes of thought beyond the domain of natural phenomena to a wide range of cultural issues that involve human interactions and value structures. He concludes that the rise of Presocratic science and the intrusion of its 'attitudes and 
ideas into a collapsing intellectual structure accelerated the downfall of traditional beliefs, and was decisive in shaping and forming the religious, ideological, and moral traditions that replaced those grounded in Homer'. ${ }^{27}$ The general thesis seems plausible enough, especially for modern times in which science and technology play an increasingly larger role in our lives, but a detailed and convincing articulation of the theme for the Presocratic period remains to be done.

\section{Koestler's Sleepwalkers}

Another innovative approach to Presocratic science flowed from the pen of the novelist Arthur Koestler into his book The Sleepwalkers: A History of Man's Changing Vision of the Universe. Koestler was interested in the psychological process of discovery and in the process that initially blinds a person towards truth which, once perceived, is regarded as heartbreakingly obvious. ${ }^{28} \mathrm{He}$ examined the unconscious biases and philosophical and political prejudices of astronomers and scientists more than a decade before the physicist and historian of science Gerald Holton coined the term themata to describe the underlying beliefs, values, and world views that lie behind the quasi-aesthetic choices that scientists make and which guide their leaps across the chasm between experience and basic principle. ${ }^{29}$ No branch of science, Koestler asserted, whether ancient or modern, could claim freedom from metaphysical bias of one kind or another. Although the progress of science generally was regarded as a clean, rational advance along a straight, ascending line, in fact it zigged and zagged, so Koestler argued, nearly two decades before Thomas Kuhn questioned the common notion of scientific progress. ${ }^{30} \mathrm{He}$ saw that the history of cosmic theories, in particular, was a history of collective obsessions and controlled schizophrenias, more of a sleepwalker's performance than of an electronic brain.

Then, in Kepler's unfolding story, came Pythagoras, whose influence on the ideas of the human race was all-encompassing, uniting religion and science, mathematics and music. He took the first steps toward the mathematisation of human experience, the beginning of science. His emphasis was on form, proportion, and pattern, on the relation rather than on the relata. The Pythagorean dream that musical harmony governed the motion of the stars, though, more a dream dreamt through a mystic's ear than a working hypothesis, more a poetic conceit than a scientific concept, retained its mysterious impact, reverberating through the centuries and calling forth responses from the depth of the unconscious mind. In the sixteenth century Kepler, enamoured of the Pythagorean 
dream, used its foundation of fantasy to build, by equally unsound reasoning, the solid edifice of modern astronomy.

\section{Scientific Highlights}

Koestler attracted few followers, and interest in Presocratic cosmology moved back to the ideas themselves and to the argument that they represented increasing rationality on the road to modern science. Marshall Clagett, one of the first professional historians of science emerging from university studies in the United States after World War II, insisted in his Greek Science in Antiquity that the tone of much of Presocratic philosophy was rational, critical, often secular, and nonmythological. He argued that the critical spirit that emerged from this period was of great significance for the subsequent growth of science, especially the emergence of a theoretical and abstract science, in which sets of empirical rules were replaced by more generalised ones. Clagett did admit that the schemes of Thales and his successors originated in analogies and patently insufficient observational data. The Pythagoreans, on the other hand, used mathematics to deepen the ties between their theoretical explanation of nature on the one hand and their experience of nature on the other. ${ }^{31}$ Clagett showed enthusiasm, sympathy, and understanding, and his book has yet to be displaced. It has, though, been characterised as the last of the old-style general handbooks, concentrating on science separately from its philosophical background, as a history of scientific highlights, rather than an attempt to understand both ancient science and the society that produced it. ${ }^{32}$

Source books constitute another category of scholarly text, and for Presocratic science there is A Source Book in Greek Science. The editors, Morris Cohen and I. E. Drabkin, a philosopher and a classicist, realised that it was an error to study the past exclusively from the point of view of current conceptions, judging ancient science according to modern criteria, but they also were concerned to discriminate between genuine science and folklore. ${ }^{33}$ The resulting book has been criticised for looking at ancient science through modern quantitative spectacles, concentrating on only the highest and most successful examples, which happen to be mathematics, astronomy, and mathematical geography. The editors included only what they regarded as scientific material and omitted any reference to philosophical speculation. In any future source book more attention should be given to the intellectual background and how the ancients organised and systematised their own thinking about nature. The case that this should be so has already been convincingly made. ${ }^{34}$ 
Cohen and Drabkin's failure to consider the broader context of the development of quantifiable science is hardly new, and is characteristic of many previous histories. Thomas Kuhn, a critic of such work, described its methods. He wrote that it sought 'to clarify and deepen an understanding of contemporary scientific methods or concepts by displaying their evolution. Committed to such goals, the historian characteristically chose a single established science or branch of science one whose status as sound knowledge could scarcely be doubted - and described when, where, and how the elements that in his day constituted its subject matter and presumptive method had come into being. Observations, laws, or theories which contemporary science had set aside as error or irrelevancy were seldom considered unless they pointed a methodological moral or explained a prolonged period of apparent sterility'. In Kuhn's words the scientist-historian viewed 'the development of science as a quasi-mechanical march of the intellect, the successive surrender of nature's secrets to sound methods skilfully deployed'. Only gradually have historians of science come 'to see their subject matter as something different from a chronology of accumulating positive achievement in a technical specialty defined by hindsight ${ }^{35}$

\section{Precursor to Modern Science}

One of the most positive appraisals of Milesian philosophy vis-à-vis modern science was written in the 1950s by S.Sambursky, a physicist. In The Physical World of the Greeks he purported to find striking similarities between patterns of thought in ancient Greek and modern science, and he presented 'noteworthy examples of the scientific approach that in the sixth century opened up a new era in the history of systematic thought...the teaching of the Milesian philosophers, which is remarkable for its rationalism' ${ }^{36}$ Sambursky was less enthusiastic about the Pythagoreans, though he did concede that their application of mathematics to basic physical phenomena conformed with correct modern method. Despite the similarity of formal scientific approach, however, Sambursky claimed an essential difference: the Pythagoreans extrapolated humanity into the cosmos, while modern science attempts to project mathematical and physical laws into man. ${ }^{37}$

Sambursky came to his study with a background in science and emphasised the emergence of modern science. Jacob Bronowski, on the other hand, came as a mathematician and, not surprisingly, focused his attention and his film 'The Music of the Spheres' (in The Ascent of Man series) on Pythagoras's search for a basic relation between mathematics 
and phenomena of nature. In his view progress in astronomy and physics followed from their amenability to mathematical treatment, and the laws of nature have been made of numbers since Pythagoras said number was the language of nature. ${ }^{38}$

Even more positive regarding the Pythagorean contribution to human advance were Olaf Pedersen, a historian of science, and his co-author Mogens Pihl, a physicist. In Early Physics and Astronomy: A Historical Introduction, they wrote that 'there is a mathematical structure behind the visible universe; the description of nature must therefore be expressed in terms of mathematics. From now on [after Pythagoras], this connection between physics and mathematics takes a progressively stronger hold upon the minds of natural philosophers, and must be thought of as the most important contribution to the advancement of science made by the Pythagoreans. It retained its fascination, and its inspiration to scientists persisted even after the specific Pythagorean doctrines had been abandoned as naïve or as obscure manifestations of an arbitrary number mysticism'. ${ }^{39}$ This book was intended as an introductory textbook, and certain choices had to be made. Still, as one reviewer asked: 'Is it best to present the many physical concepts in a manner that is readily intelligible to the modern reader even if it means mathematising what was often rendered verbally and wrenching out of context ideas that may have been submerged in philosophical, metaphysical, and even theological discussion? And is it justifiable to concentrate on those aspects of ancient and medieval physical thought that adumbrated or heralded ideas and concepts that would prove significant in the scientific revolution, while ignoring by far the largest portion of early physical thought which might strike the modern reader as crude and irrelevant? ${ }^{40}$

\section{Rational Debate}

Enthusiasm was expressed for the Milesians by the classicist G.E.R.Lloyd, though not because of any purported similarities with modern science. In Early Greek Science: Thales to Aristotle, Lloyd finds two major achievements of Milesian philosophy: the rejection of supernatural explanations of natural phenomena and the institution of the practice of rational criticism and debate. He saw that dogmatic though Presocratic philosophers were in presenting their answers, still they tackled the same problems, investigated the same natural phenomena, and were aware of the need to examine and assess their opponents' theories. Lloyd attributes this practice of debate to political conditions in Greece 
and an extension of the customs of political debate to scientific inquiry. ${ }^{41}$ 'But', he wrote, 'while philosophy and science did not involve a different mentality or a new logic, they may be represented as originating from the exceptional exposure, criticism and rejection of deep-seated beliefs...So far as an additional distinctively Greek factor is concerned, our most promising clue (to put it no more strongly) lies in the development of a particular social and political situation in ancient Greece, especially the experience of radical debate and confrontation in small-scale, face-to-face societies...(and) those who deployed evidence and argument were at an advantage..., ${ }^{42}$

Jonathan Barnes, too, in The Presocratic Philosophers emphasises the role of open debate in the development of cosmology and considers that 'What is significant is not that theology yielded to science or gods to natural forces, but rather that unargued fables were replaced by argued theory, that dogma gave way to reason...Few Presocratic opinions are true; fewer still are well grounded. For all that, they are, in a mild but significant sense, rational: they are characteristically supported by argument, buttressed by reasons, established upon evidence'. ${ }^{43}$ Farrington earlier had argued from a different position in Science and Politics in the Ancient World. Far from political debate fostering science, he argued that scientific activity had declined in the ancient world when the struggle between science and obscurantism ultimately became a political struggle. He thought that scientific schools did save the Greeks from hierarchic petrification, but only temporarily. He drew attention to the threat Ionian philosophy posed to the institution of the state cult, and the Ionian philosopher Anaxagoras' (c.500 - c.428 BC) expulsion from Athens after his new theory of universal order posed a threat to the popular belief that celestial phenomena were controlled by the gods. ${ }^{44}$ Actually, Anaxagoras was indicted both for impiety and for corresponding with agents of Persia, whose subject he formerly had been. ${ }^{45}$ Some historians choose to believe that the jury which judged him responded at least in part to the avowed charges of impiety, while other scholars elect 'to emphasise immediate political reasons for the persecution and downplay the claimed science-impiety association as an incidental rationale, unimportant in itself ${ }^{46}{ }^{46}$

Ludwig Edelstein, a classicist, medical historian, and philosopher, was not convinced that Farrington had sufficient evidence to uphold his argument on the interaction between science and politics. 'In every respect, then,' he wrote, 'Farrington's explanation of the development of ancient science seems to be untenable. His books have done much to 
arouse interest in the subject. The thesis which they advocate is vitiated however by what, in my opinion, is the basic error in many of the recent evaluations of ancient science, namely, the misapplication of historical analogies. Conditions in antiquity are seen in the light of subsequent events. The conflict between science and religion, which characterised later ages, is injected into the ancient world. Progress and decay of Greek and Roman science are judged by the standards of modern science. ${ }^{, 47}$ Whatever the merits of this criticism, which Farrington had invited upon himself by citing examples from modern times to support his contention that interaction between science and politics does take place, Farrington's interpretations of ancient science have failed to attract a significant following.

Many historians are open to the charge of overemphasising in the past problems of the present. Indeed, as Richard Olson has written, there exists 'near paranoia about the whiggishness of the history of science as a discipline. We seem to agree on almost nothing but the need to avoid imposing inappropriate modern categories upon historical activities, and the need to otherwise avoid reading the present into the past. Thus, we are almost apologetic about speaking of Greek science at all..., ${ }^{48}$

\section{The Pythagoreans}

Lloyd, while relatively enthusiastic about the Milesians, is only lukewarm when it comes to the Pythagoreans. The two philosophies were distinguished by their religious beliefs and cosmological theories. Granted, the Pythagoreans were the first to give knowledge of nature a quantitative, mathematical foundation, and hence could be considered scientific. Yet they held not only that phenomena are expressible in numbers, but also that things are made of numbers, this defying most modern conceptions of science. Furthermore, Lloyd concludes, 'many of the resemblances that the Pythagoreans claimed to find between things and numbers were quite fantastic and arbitrary,. ${ }^{49}$ The Pythagoreans attracted few followers in ancient times, and Lloyd, who writes only about ancient science, rightly accords them scant attention. Those who look ahead to the Renaissance, and particularly to Kepler, though they need not attribute to the original Pythagoreans all the importance later followers achieved, cannot ignore the Pythagorean emphasis on number. At least, most cannot. James Coleman, a scientist-historian, was so distressed, however, with incorrect opinions, that when he reached Kepler in his Early Theories of the Universe, he could not bring himself to mention Pythagoras by name. 'Kepler, too,' he wrote, 'was a victim of 
the fallacious reasoning of his predecessors, but even though Kepler was often forced to many years of fruitless labour because of convictions and philosophies about the universe which he inherited, he was quick to renounce not only the erroneous arguments of predecessors but his own follies as well when this path was indicated. The clearing away of the debris enabled Kepler, with his prodigious persistence, finally to be led to the first correct description of the seemingly haphazard motions of the planets. $^{50}$

This perception of Kepler, fighting free of evil Pythagorean influence rather than beneficently guided by it, along with the author's focus on correctness, enabled him to see that the Pythagoreans' main contribution lay not in using mathematics to increase ties between theoretical explanation of nature on the one hand, and experience of nature on the other, as have most writers on Presocratic science, but instead in their discovery that the earth is round. Also, Coleman repeatedly found it necessary to remind his readers that the Milesians' ideas were not correct: 'That Thales was incorrect' he wrote 'is obvious in the light of the relatively vast knowledge of today...Its importance lay not in the model itself, which today is known to be incorrect, but in the fact that Anaximander was the first person to reduce the workings of the universe to a mechanical system...The "model" itself was incorrect in the light of today's knowledge, but before the facts could be established a long chain of progressively correct interpretation of astronomical discoveries had to be established. ${ }^{51}$

In contrast to those scientist-historians who are perhaps more enthusiastic than erudite, Thomas L.Heath is a respected scholar whose pioneering work on Greek science remains a valuable source. In terms of emphasis and interpretation, however, his major book on early Greek astronomy falls among the older histories of science since castigated by Kuhn as chronologies of accumulating positive achievement seldom considering observations, laws, and theories which contemporary science has set aside as erroneous or irrelevant. ${ }^{52}$ Heath set himself the stated task of 'tracing every step in the progress toward the true Copernican theory' and showing 'that Aristarchus [not Heraclides of Pontus, as Giovanni Schiaparelli had asserted] was the real originator of the Copernican hypothesis' ${ }^{53} \mathrm{He}$ looked primarily at those discoveries and observations validated as scientific by modern standards: 'Thales' claim to a place in the history of scientific astronomy depends almost entirely on one achievement attributed to him, that of predicting an eclipse of the sun, ${ }^{, 54}$ while "Anaximander boldly maintained that the earth is in the centre of 
the universe... ${ }^{55}$ The first sentence of his chapter on Anaximenes began: 'For Anaximenes of Miletus...the earth is still flat...' ${ }^{56}$ while he described Anaxagoras as 'A great man of science (who) enriched astronomy by one epoch-making discovery. This was nothing less than the discovery of the fact that the moon does not shine by its own light but receives its light from the sun. As a result, he was able to give (though not without an admixture of error) the true explanation of eclipses. ${ }^{57}$ Pythagoras is credited with his eponymous theorem, with inventing the science of acoustics, his discovery regarding musical tones, and a spherical earth, but there is not even a hint that he had anything to do with some mystical philosophy regarding a relationship between mathematics and phenomena of nature. The remarkable development by later Pythagoreans, in Heath's opinion, was their abandonment of the geocentric hypothesis. ${ }^{58}$

\section{Thales' Eclipse Prediction}

Thales' purported eclipse prediction marks for many scientist-historians the beginning of Western astronomical science. Retrospective astronomical calculations showing a total solar eclipse on 28 May 584 BC in Northern Turkey, help confirm Herodotus' report that 'In the sixth year of the war, which they [the Medes and the Lydians] had carried on with equal fortunes, an engagement took place in which it turned out that when the battle was in progress the day suddenly became night. This alteration of the day Thales the Milesian foretold to the Ionians, setting as its limit this year in which the change actually occurred. ${ }^{59}$ Presumably the warring parties either took the eclipse of the sun as a sign to cease fighting, or they were eager for any reason to cease and found the eclipse a convenient excuse. Most historical discussion has centred not on the credibility of the tradition itself, but on what methods Thales could have used to predict the solar eclipse. Willy Hartner has argued that Thales could have predicted an eclipse before the end of 583 BC from a study of the periodic recurrence of solar eclipses, and then taken credit for a different eclipse occurring slightly earlier. ${ }^{60}$

Thales' prediction of the solar eclipse of 584 BC may, however, be more myth than historic truth and as Alden Mosshammer has pointed out, 'As modern research in the history of ancient science and mathematics has advanced, confidence in Thales' ability to predict a solar eclipse has receded'. ${ }^{61}$ Weighing in with the most caustic damnation of the credulity of his naive colleagues is Dicks, who found their conclusions 'totally at variance with the available evidence... of Thales' alleged prediction of a solar eclipse. In a desperate attempt to vindicate the historicity of this 
prediction, [the scholar] spins a web of inferential reasoning, based on wholly improbable suppositions...presupposing not only accurate observations, but also the concept of the ecliptic...the assumption that such comparatively advanced astronomical knowledge was possible in the sixth century BC is ludicrous; as we have seen, all the indications are...that such a stage was not reached until at least 150 years later'. ${ }^{62}$

\section{Fresh Views}

Providing a welcome contrast to the older-type histories is Stephen Toulmin and June Goodfield's The Fabric of the Heavens. He was trained as a physicist but later became a historian of science, and she was trained by him as a historian of science. In a series of books on the development of scientific thought, they set out 'to illustrate and document the manner in which our chief scientific ideas have been formed' ${ }^{63}$ This beginning could all too easily have led to yet another chronology of accumulating positive achievement, but they realised that 'to understand fully the scientific traditions which we have inherited, it is not enough to discover what our predecessors believed and leave it at that: we must try to see the world through their untutored eyes, recognize the problems which faced them, and so find out for ourselves why it was that their ideas were so different from our own...Different situations gave rise in earlier times to different practical demands; different practical demands posed different intellectual problems; and the solution of these problems called for systems of ideas which in some respects are not even comparable with our own'. ${ }^{64}$ In other words the Presocratics did have some ideas which are now judged correct, but they did not elaborate, test them, or prove them. The union of theory and practice characteristic of modern science came later. Presocratic science was purely an intellectual enterprise undertaken with no technological end in view. For wild generalisation or unsound theorising or incautious analogy there was no potential penalty to pay in bridges collapsed or lives lost, and hence also no shackles on originality and imagination. ${ }^{65}$ On the Pythagoreans, Toulmin and Goodfield argued that 'the most grandiose ambition they conceived was to explain all the properties of nature in arithmetical terms alone', and their 'belief that the distances of the planets from the centre of their orbits fit a simple "harmonious" mathematical law was the life-long conviction of Kepler, two thousand years later, and inspired the whole course of his astronomical researches' ${ }^{66}$

The intellectual nature of Presocratic science and the separation of theory from practice are also themes in a joint appraisal of the 
Pythagoreans by Bernard R.Goldstein and Alan C.Bowen, a historian of science and a classicist. They wrote that 'The Pythagoreans regarded the explanation of the heavenly motions in terms of these ratios as knowledge of the speeds, risings, and settings of the celestial bodies; and Plato called it astronomy. But, though such speculation did relate celestial movement and number, it would be wrong to see in this any attempt at precise measurement of what is observed. The explanandum in these theories is not so much a physical phenomenon as the ethical and aesthetic order it supposedly exhibits. ${ }^{67}$

A possible explanation of the Presocratic attitude toward theories, especially the apparent lack of interest in testing them, focuses on their emphasis on problems of cosmogony (how the world came into being) rather than of cosmology (the current structure and future evolution of the world), and the consequent direction of their scientific efforts to the past than to the present and the future. 'As might have been expected in an age whose central problem was cosmogony, i.e., a set of unobservable and unrepeatable phenomena, and which, moreover, lacked all magnifying devices, the need for increased factual knowledge and for testing assumptions by experience was hardly felt. The facts to be explained were supposed to be matters of common knowledge, and any endeavour to account for them was essentially like the effort to solve a riddle. A scientific hypothesis was a (more or less fortunate) guess and the only criterion of its validity was its intrinsic plausibility. ${ }^{, 68}$ Lloyd, too, makes the point that much of the Presocratics' speculative effort was concentrated on astronomy, and though there might be attempts to verify theories with future observations, astronomy, strictly speaking, is not an experimental science, as it was impossible to vary or govern conditions of the objects under observation; direct experimentation was therefore impossible. ${ }^{69}$

\section{Popper's Philosophy}

The Presocratics may not have tested their theories, but did they discuss them? The matter of a tradition of critical discussion has been raised in a philosophical context by the philosopher of science Karl Popper. He asked wherein does the much discussed 'rationality' of the Presocratics lie? Not in any empiricism, because the Presocratics were critical and speculative rather than empirical. Yet when Popper wrote this, in the late $1950 \mathrm{~s}$, both traditional empiricist epistemology and traditional historiography of science were still, according to him, deeply influenced by the Baconian myth that science starts from observation and then 
slowly and cautiously proceeds to theories. ${ }^{70}$ Science, according to this myth, began only when the speculative method was replaced by the observational method, when deduction was replaced by induction. For Popper, however, observations and experiments do not lead to an expansion of conjectural or hypothetical knowledge. Instead, observations and experiments play only the role of critical arguments, and their significance lies entirely in how they may be used to criticise theories. ${ }^{71}$ From this theory of knowledge, it was but a short step for Popper to identify the modern rationalist tradition with the ancient Greek tradition of critical discussion. He identified the element of rationality in the Presocratics' thought in their attempt to know the world as the critical self-examination of their theories. Knowledge, Popper argued, proceeds by way of conjecture and refutation, and Presocratic philosophy developed through the clash of ideas in a critical debate. ${ }^{72}$

While pursuing his discussion of scientific methodology Popper somewhat inadvertently criticised Kirk's interpretation of Heraclitus. Kirk felt compelled to reply, upholding his interpretation of Heraclitus and also attempting to chip away at Popper's view of science. ${ }^{73}$ Lloyd dismisses much of the squabble between Popper and Kirk as more of a difference between academic specialities than a disagreement over content. He also shows persuasively that broadening the question of scientific methodology to other fields of early Greek science produces different answers and rightly considers it a minor scandal that the debate initiated by Popper fizzled out so quickly. ${ }^{74}$

Following Popper, Lloyd further emphasised debate among the Presocratics in an article a few years later. 'Greek cosmology is nothing if not dialectical. And this is not an accidental or contingent feature of Greek cosmology, but of the essence of the Greek contribution. ${ }^{75}$ Greek cosmologists were in competition with each other for the best explanation, for the most adequate theory, and had 'an awareness of the need to examine and assess theories in the light of the grounds adduced for them...The history of early Greek cosmology is one of argument and counter-argument with a paucity of references to empirical data, and those mostly familiar ones'. ${ }^{76}$

\section{Conclusion}

Popper's philosophical emphasis has not won over classicists. Indeed, much of the disagreement over the nature of Presocratic cosmology can be understood in terms of the interests of different academic specialities and different assumptions about the nature of science. As Holton has 
observed: 'The search for answers in the history of science is itself imbued with themata...we must be prepared for the criticisms of those who are afflicted, not with our themata, but with their antithemata. ${ }^{, 77}$ And from Lloyd: "whether or not historians make explicit their views on the philosophy of science, the history they write will inevitably incorporate judgements, on the nature of science itself, on what demarcates it from other inquiries, on scientific methodology. ${ }^{78}$

With a limited amount of raw material, each new thesis quickly exhausts inherent possibilities. Interpretations of Pythagorean and Milesian cosmology and culture have little chance of becoming paradigms for the practice of what we might term 'normal' history, in analogy to Thomas Kuhn's normal science, which finds practitioners in agreement upon certain basic problems and techniques and industriously expanding and elaborating an initial idea. Here, Lloyd's work may turn out to be a happy exception to the general absence of sustainable intellectual themes in studies of early Greek cosmology. Also, Lloyd avoids the extremes of both scientist-historian and classicist; he offers historical perspective tempered by critical sense, and shows the forest as well as the trees. It is no easier to imagine means for testing speculations about Presocratic cosmology and culture than it was for the Presocratics to test their own speculations. Caught up in an intellectual speculative fever, we must be cautious lest we become so entranced that we lose our footing.

\section{References}

1. Victor E. Thoren, review of D. R. Dicks, Early Greek Astronomy to Aristotle, (Ithaca, New York: Cornell University Press, 1970), in Isis, 61 (1970), 541-2.

2. William D. Stahlman, review of G. S. Kirk, ed., Heraclitus, the Cosmic Fragments (Cambridge: Cambridge University Press, 1954), in Isis, 45 (1954), 308-9. For disagreement among the trees, see Gregory Vlastos, 'On Heraclitus', American Journal of Philology, 76 (1955), 337-68; reprinted in David J. Furley and R. E. Allen, eds., Studies in Presocratic Philosophy. Vol. 1, The Beginnings of Philosophy (London: Routledge \& Kegan Paul, 1970), pp. 413-29.

3. A very brief characterisation of the two philosophies has the Milesians driven by intellectual curiosity and dissatisfaction with the old mythological models to create a systematic natural explanation for physical and celestial phenomena, but their theories tended to be untestable and dogmatic, and if evidence clashed with dogma they preferred the dogma. The Pythagoreans were more concerned with metaphysical explanations and driven more by religious imperatives than scientific ones. The Pythagoreans were characterized by Aristotle: 'the Pythagoreans, as they are called, devoted themselves to mathematics; they were the first to advance this study, and having been brought up in it they thought its principles were the principles of all things...things seemed in their whole 
28 Early Greek Cosmology: A Historiographical Review

nature to be modelled after numbers, and numbers seemed to be the first things in the whole of nature, they supposed the elements of numbers to be the elements of all things, and the whole heaven to be a musical scale and a number.' (Metaphysics I 5, 985b23986a3) And Aristotle on the Milesians: 'Most of the first philosophers thought that principles in the form of matter were the only principles of all things: for the original source of all existing things, that from which a thing first comes-into-being and into which it is finally destroyed, the substance persisting but changing in its qualities, this they declare is the element and first principle of existing things, and for this reason they consider that there is no absolute coming-to-be or passing away, on the ground that such a nature is always preserved...for there must be some natural substance, either one or more than one, from which the other things come-into-being, while it is preserved. Over the number, however, and the form of this kind of principle they do not all agree; but Thales, the founder of this type of philosophy, says that it is water (and therefore declared that the earth is on water), perhaps taking this supposition from seeing the nurture of all things to be moist, and the warm itself coming-to-be from this and living by this (that from which they come-to-be being the principle of all things) - taking the supposition both from this and from the seeds of all things having a moist nature, water being the natural principle of moist things'(Metaphysics I 1, 983b6-27). An important book on Pythagoreanism is Walter Burkert's Lore and Science in Ancient Pythagoreanism (Harvard UP), 1972), which has a long section on astronomy. Also of note are the long chapter on astronomy in C.A.Huffman, Philolaus of Croton (Cambridge UP, 1993) and Maria Papathanassiou, 'The Influence of Pythagorean Philosophy on the Development of Mathematical Astronomy', in K.I.Boudouris (ed.), Pythagorean Philosophy (Athens, 1992). A good overall study is D.J.Furley, The Greek Cosmologists, Cambridge UP, 1987.

4. M. L. West, 'Alcman and Pythagoras', Classical Quarterly, 61 (new series 17), (1967), $1-15$.

5. G. S. Kirk, J. E. Raven, and M. Schofield, The Presocratic Philosophers: A Critical History with a Selection of Texts, 2nd. ed. (Cambridge: Cambridge University Press, 1983). Astronomical and cosmological material from this volume has been abstracted in Norriss S. Hetherington, Ancient Astronomy and Civilization (Tucson, Arizona: Pachart, 1987); see also 'Early Greek Cosmology', in Hetherington, ed., Encyclopedia of Cosmology: Historical, Philosophical, and Scientific Foundations of Modern Cosmology (New York: Garland, 1993), pp. 183-8, and 'The Presocratics', in Hetherington, ed., Cosmology: Historical, Literary, Philosophical, Religious, and Scientific Perspectives (New York: Garland, 1993), pp. 53-66. For entry into the voluminous literature on the Presocratics, see the introduction to bibliographic tools in the editor's supplement (pp. xvii-xxvii) and selective bibliographies to 1974 (pp. 527-542) and from 1973 to 1993 (pp. xxix-xlvii) in Alexander P. D. Mourelatos, The Pre-Socratics: A Collection of Critical Essays, revised ed. (Princeton, New Jersey: Princeton University Press, 1993), and Luis E. Navia, The Presocratic Philosophers: An Annotated Bibliography (New York: Garland, 1993). The major bibliography is L. Paquet, M. Roussel, and Y. Lafrance, Les Présocratiques: Bibliographie analytique (1879-1980), 2 vols. (Montreal: Bellarmin, 1988-89). Also see R.D.McKirahan, Philosophy Before Socrates, Hackett, 1994.

6. Kirk, Heraclitus (ref. 2), p. 30. See especially H. F. Cherniss, Aristotle's Criticism of Presocratic Philosophy (Baltimore: Johns Hopkins University Press, 1935); summarized in 'The Characteristics and Effects of Presocratic Philosophy', Journal of the History of Ideas, 12 (1951), 319-45; reprinted in Furley and Allen, Studies in Presocratic Philosophy (ref. 2), pp. 1-28. Cherniss' thesis is criticized not as incorrect, but perhaps as going rather too far, in W. K. C. Guthrie, 'Aristotle as a Historian: Some Preliminaries', Journal of 
Hellenic Studies, 77 (1957), 35-41; reprinted as 'Aristotle as a Historian', in Furley and Allen, ibid., pp. 239-54. For a criticism, in turn, of Guthrie's article, see J. G. Stevenson, ‘Aristotle as a Historian of Philosophy', Journal of Hellenic Studies, 94, (1974), 138-43. See also J. B. McDiarmid, 'Theophrastus on the Presocratic Causes', Harvard Studies in Classical Philology, 61 (1953), 85-156; reprinted, with abridgments, in Furley and Allen, ibid., pp. 178-238. An important new work, taking a fresh look at the Aristotelian view of the Presocratics, is Peter Kingsley, Ancient Philosophy, Mystery and Magic, Oxford UP, 1995.

7. Thoren, review of Dicks, Early Greek Astronomy to Aristotle (ref. 1).

8. D. R. Dicks, 'Solstices, Equinoxes, \& the Presocratics', Journal of Hellenic Studies, 86 (1966), 26-40.

9. D. R. Dicks, 'Thales', Classical Quarterly, 53 (new series 9), (1959), 294-309.

10. Dicks, 'Solstices, Equinoxes, \& the Presocratics', (ref 8).

11. Charles H. Kahn, 'On Early Greek Astronomy', Journal of Hellenic Studies, 90 (1970), 99-116. See also 'Some Remarks on the Origins of Greek Science and Philosophy', in Alan C. Bowen, ed., Science and Philosophy in Classical Greece (New York: Garland, 1991), pp. 1-10.

12. Jonathan Barnes, The Presocratic Philosophers, rev. ed. (London: Routledge \& Kegan Paul, 1981), pp. 47-8; Heinrich Gomperz, 'Problems and Methods in Early Greek Science', Journal of the History of Ideas, 4 (1943), 61-76; reprinted in Daniel S. Robinson, ed., Philosophical Studies by Heinrich Gomperz (Boston: Christopher, 1953), pp. 72-87, and in Philip P. Wiener and Aaron Noland, eds, Roots of Scientific Thought: A Cultural Perspective (New York: Basic Books, 1957), pp. 23-38.

13. Barnes, ibid., p. 48

14. G. E. R. Lloyd, 'Greek Cosmologies', in Carmen Blacker and Michael Loewe, Ancient Cosmologies (London: George Allen \& Unwin, 1975), pp. 198-224. Reprinted, with an introduction assessing scholarly debate on the topic and Lloyd's modifications and developments in his own position since the original publication of the article, in Lloyd, Methods and Problems in Greek Science (Cambridge: Cambridge University Press, 1991), pp. 141-63.

15. Francis Macdonald Cornford, From Religion to Philosophy: A Study in the Origins of Western Speculation, 2nd ed. (Sussex: Harvester Press, 1983), pp. v-vii. Original edition, London: Edward Arnold, 1912.

16. Ibid., p. 143.

17. Ibid., p. 144.

18. Giorgio de Santillana, The Origins of Scientific Thought: from Anaximander to Proclus 600 B.C.-500 A.D. (Chicago: University of Chicago Press, 1961), p. 21.

19. Francis Macdonald Cornford, Before and After Socrates (Cambridge: Cambridge University Press, 1932), pp. 5, 7-8.

20. F. M. Cornford, 'Was the Ionian Philosophy Scientific?' Journal of Hellenic Studies, 62 (1942), 1-7; reprinted in Furley and Allen, Studies in Presocratic Philosophy (ref. 2), pp. 29-41. See also Cornford, Principium Sapientiae: The Origins of Greek Philosophical Thought (Cambridge: Cambridge University Press, 1952).

21. Gregory Vlastos, 'Cornford's Principium Sapientiae', Gnomon, 27 (1955), 65-76; reprinted in Furley and Allen, Studies in Presocratic Philosophy (ref. 2), pp. 42-55. Also see W.A.Heidel, The Heroic Age of Science (Baltimore, 1933) and Robin Waterfield, Before Eureka, The Presocratics and their Science, Bristol Press, 1989, Ch. 9

22. Benjamin Farrington, Science in Antiquity, 2nd ed. (Oxford: Oxford University Press, 1969), pp. 20-1, 27-8. 
30 Early Greek Cosmology: A Historiographical Review

23. Stephen Toulmin and June Goodfield, The Fabric of the Heavens (London: Hutchinson, 1961), p. 64.

24. Bertrand Russell, A History of Western Philosophy and Its Connections with Political and Social Circumstances from the Earliest Times to the Present Day (New York: Simon and Schuster, 1945), p. 31.

25. Benjamin Farrington, Greek Science (Harmondsworth: Penguin Books, 1953), pp. 3640, 48-9.

26. Jean Pierre Vernant, Mythe et pensee chez les Grecs (Paris: Libraire Francois Maspere, 1965); translated as Myth and Thought among the Greeks (London: Routledge \& Kegan Paul, 1983), pp. 181-6, 190.

27. Richard Olson, Science Deified \& Science Defied: The Historical Significance of Science in Western Culture. vol 1. From the Bronze Age to the Beginnings of the Modern Era ca. 3500 B.C. to ca A.D. 1640 (Berkeley: University of California Press, 1982), pp. 62,72 .

28. Arthur Koestler, The Sleepwalkers: A History of Man's Changing Vision of the Universe (New York: Grosset \& Dunlap, 1959), p. 14.

29. Gerald Holton, 'Themata in Scientific Thought', in The Scientific Imagination: Case Studies (Cambridge: Cambridge University Press, 1978), pp. 3-24. An earlier version of this essay, followed by commentary, appeared in Holton, 'Themata in Scientific Thought', Science, 188 (1975), 328-34, and Robert K. Merton, 'Thematic Analysis in Science: Notes on Holton's Concept', ibid., 335-8. On thematic analysis see also Holton, Thematic Origins of Scientific Thought: Kepler to Einstein (Cambridge, Massachusetts: Harvard University Press, 1973).

30. Thomas S. Kuhn, The Structure of Scientific Revolutions, 2nd ed., enlarged (Chicago: University of Chicago Press, 1970).

31. Marshall Clagett, Greek Science in Antiquity (London: Abelard-Schuman, 1955), pp. $34-35,42,43$.

32. J. T. Vallance, 'Marshall Clagett's Greek Science in Antiquity: Thirty-five Years Later', Isis, 81 (1990), 713-21.

33. Morris R. Cohen and I. E. Drabkin, eds., A Source Book in Greek Science, 2nd ed. (Cambridge, Massachusetts: Harvard University Press, 1958), p. vii. See also Cohen, $A$ Dream's Journey: The Autobiography of Morris Raphael Cohen (Boston: Beacon Press, 1949), p. 193.

34. Vallance, 'Marshall Clagett's Greek Science in Antiquity', (ref. 32).

35. Thomas S. Kuhn, 'The History of Science', in International Encyclopedia of the Social Sciences, vol. 14 (New York: Crowell Collier and Macmillan, 1968), pp. 74-83; reprinted in Kuhn, The Essential Tension: Selected Studies in Scientific Tradition and Change (Chicago: University of Chicago Press, 1977), pp. 105-26.

36. S. Sambursky, The Physical World of the Greeks (London: Routledge and Kegan Paul, 1956), pp. 4-5. Translated by Merton Dagut from the Hebrew edition, Kosmos shel ha-Yevanim (Jerusalem: Bialik Institute, 1954).

37. Ibid., pp. 40, 42.

38. Jacob Bronowski, 'Music of the Spheres', 52-minute color film in The Ascent of Man series, no. 5 (BBC-TV and Time-Life Films, 1973, $16 \mathrm{~mm}$. and videotape). See also Bronowski, The Ascent of Man (Boston: Little, Brown and Company, 1973), p. 187.

39. Olaf Pedersen and Mogens Pihl, Early Physics and Astronomy: A Historical Introduction, 2nd ed. (Cambridge: Cambridge University Press, 1994), pp. 17, 20.

40. Edward Grant, 'Physical Sciences before the Renaissance', Journal for the History of Astronomy, 7 (1976), 201-204. Grant's review was of the 1st edition of Pederson and Pihl. 
41. G. E. R. Lloyd, Early Greek Science: Thales to Aristotle (London: Chatto \& Windus, 1970), pp. 13-4.

42. G. E. R. Lloyd, Magic, Reason, and Experience: Studies in the Origin and Development of Greek Science (Cambridge: Cambridge University Press, 1979), pp. $265-$ 6.

43. Barnes, The Presocratic Philosophers (ref. 12), p. 45.

44. Benjamin Farrington, Science and Politics in the Ancient World (London: George Allen \& Unwin, 1939), pp, 70-1, 74-6.

45. T. W. Africa, Science and the State in Greece and Rome (New York: John Wiley \& Sons, 1968), p. 39

46. Richard Olson, 'Science, Scientism and Anti-Science in Hellenic Athens: A New Whig Interpretation', History of Science, 14 (1978), 179-99; Olson, Science Deified \& Science Defied (ref. 27), pp. 79-82.

47. Ludwig Edelstein, 'Recent Trends in the Interpretation of Ancient Science', Journal of the History of Ideas, 1952, 13:573-604; reprinted in Wiener and Noland, eds., Roots of Scientific Thought (ref. 12), pp. 90-121, and in Owsei Temkin and C. Lilian Temkin, eds., Ancient Medicine: Selected Papers of Ludwig Edelstein (Baltimore: Johns Hopkins Press, 1967), pp. 401-39.

48. Richard Olson, 'Science, Scientism and Anti-Science', p 179-199. On whiggism, priggism, presentism, contextualism, and anti-antiwhiggism, see Stephen G. Brush, 'Scientists as Historians', Osiris, 10 (1995), 215-231.

49. Lloyd, Early Greek Science (ref. 41), pp. 24-6.

50. James A. Coleman, Early Theories of the Universe (New York: New American Library, 1967), p. 106.

51. Ibid., pp. 18, 21, 22 .

52. Kuhn, 'The History of Science', (ref. 35).

53. Thomas Heath, Aristarchus of Samos: The Ancient Copernicus. A History of Greek Astronomy to Aristarchus together with Aristarchus's Treatise on the Sizes and Distances of the Sun and Moon. A New Greek Text with Translation and Notes (Oxford: Clarendon Press, 1913), p. iv. See also Heath, Greek Astronomy (London: J. M. Dent \& Sons, 1932). 54. Heath, Aristarchus of Samos, p. 13.

55. Ibid., p. 24.

56. Ibid., p. 40.

57. Ibid., p. 78.

58. Ibid., pp. 46, 48, 94.

59. Herodotus, I, 74. See Kirk, Raven, and Schofield, The Presocratic Philosophers (ref. 5), pp. 81-2.

60. Willy Hartner, 'Eclipse Periods and Thales' Prediction of a Solar Eclipse - Historic Truth and Modern Myth', Centaurus, 14 (1969), 60-71.

61. Alden A. Mosshammer, 'Thales' Eclipse', Transactions of the American Philological Association, 111 (1981), 145-55. See also Otto Neugebauer, Exact Sciences in Antiquity, 2nd ed. (Providence, Rhode Island: Brown University Press, 1957), pp. 142-3.

62. Dicks, Early Greek Astronomy (ref. 1), p. 174.

63. Toulmin and Goodfield, The Fabric of the Heavens (ref. 23), p. 15.

64. Ibid., p. 16.

65. Ibid., pp. 68-9.

66. Ibid., pp. 79, 82 . 
32 Early Greek Cosmology: A Historiographical Review

67. Bernard R. Goldstein and Alan C. Bowen, 'A New View of Early Greek Astronomy', Isis, 74 (1983), 330-40; reprinted in Goldstein, Theory and Observation in Ancient and Medieval Astronomy (London: Variorum Reprints, 1985), pp. 1-11.

68. Gomperz, 'Problems and Methods in Early Greek Science', (ref. 12), pp. 31-2.

69. G. E. R. Lloyd, 'Experiment in Early Greek Philosophy and Medicine', Proceedings of the Cambridge Philological Society, 190 (new series 10), (1964), 50-72; reprinted, with an introduction assessing scholarly debate on the topic and Lloyd's modifications and developments in his own position since the original publication of the article, in Lloyd, Methods and Problems in Greek Science (ref. 44), pp. 70-99.

70. Karl R. Popper, 'Back to the Presocratics', Procedings of the Aristotelian Society, 59 (1958-1959), 1-24; reprinted, with additions, in Popper, Conjectures and Refutations: The Growth of Scientific Knowledge (London: Routledge and Kegan Paul, 1963), pp. 136-65, and in Furley and Allen, Studies in Presocratic Philosophy (ref. 2), pp. 130-153.

71. Ibid., on p. 151.

72. Ibid., on pp. 148-152.

73. G. S. Kirk, 'Popper on Science and the Presocratics', Mind, 69 (1960), 318-39; reprinted in Furley and Allen, Studies in Presocratic Philosophy, (ref. 2), pp. 154-77.

74. G. E. R. Lloyd, 'Popper versus Kirk: a Controversy in the Interpretation of Greek Science', British Journal for the Philosophy of Science, 18 (19670, 21-38; reprinted, with an introduction assessing scholarly debate on the topic and Lloyd's modifications and developments in his own position since the original publication of the article, in Lloyd, Methods and Problems in Greek Science (ref. 14), pp. 100-20, esp, p 105.

75. Lloyd, 'Greek Cosmologies', (ref. 14).

76. Ibid., pp. 209, 218-9.

77. Holton, 'Themata in Scientific Thought', (ref. 29).

78. Lloyd, 'Popper versus Kirk', (ref. 74), p. 100. 